\title{
THE IMAGES IN "MALEFICENT" NOVEL BY ELIZABETH RUDNICK
}

\author{
Nommariati Purba ${ }^{1}$ \\ Universitas Putera Batam \\ Ambalegin ${ }^{2}$ \\ Universitas Putera Batam \\ pb151210070@upbatam.ac.id ${ }^{1}$
}

Submit, 31-05-2020 Accepted, 30-06-2020 Publish, 30-06-2020

\begin{abstract}
This study aims to analyze the images found in the novel Maleficent by Elizabeth Rudnick in 2014. This is a descriptive qualitative study. The method of data collection is by observation (reading) and note taking (underlining). The result of the analysis is to find out the nine archetypal images. The images are water (river), sun, colors (red, green, blue, black, white), serpent, number (three), good mothers, wise old man, garden, and tree. The images are able to enlighten the fantasy moment created by the writer and bring the readers' experiences to the literary work of fantacy.
\end{abstract}

Keywords: Archetypal Image, Maleficent, Novel

\section{INTRODUCTION}

In human life there are many symbols, each symbol explains a meaning. The basic pattern is hidden in everyone and will be given a symbolic expression according to the historical situation in which the person is included (Kay, 1969). According to (Guerin et al., 2005), Similar motifs or themes can be found among many different mythologies, and certain images that appear in the myths of people who are far apart in time and place tend to have the same meaning or, more accurate.

Some myths that often arise with phenomena in everyday life such as the sound of crows at night, one of them was a news from the it was reported about the phenomenon sound of crows at night, in the title "Thousands of Crows Flying over the City of Wuhan, The people thought panickly that the crows hunted that bodies Corpses, it was found from the newspaper SINDONEWS.com on February 12, 2020 by Wahyu Budi Santoso. The crow was likened to carrying a message to people to be aware there would be a disaster. Sometimes crow interpreted as a grim reapers and often appears with big, and dark eyes.

It was reported there are thousands of crows flying around the city of Wuhan, then the birds perched on the road and pecked at something like looking 
for food. Many opinions of residents and reporters on this matter, some argues that the bird was looking for corpses to eat, another opinion is looking for ash from cremated corpses. In our daily lives a sign appears that without us realizing the meaning of a message, (Danesi, 2004). Related to the news that the crows ate corpses, so China forbade corpses infected with the corona virus were buried but immediately burned. Crows is believed to bring disaster and one's death. This issue is one of phenomenon about archetypal image that found in real life. This image is also related to the tradition and culture about the phenomenon of someone who cuts nails at night will lose fortune.

Crows is believed to bring disaster and one's death. Some people also believe that who screams by saying to go away many times when this bird comes, this is believed to keep away the danger that is coming. Some residents also believe that the appearance of crows will accompany the spirits to be taken to their resting places. (M.R., 2017), said that the crow was a sign that was interpreted as negative. Related to the news that crows ate corpses, China forbade corpses infected with the corona virus were buried but immediately burned. The problem is the number of infected victims is already in fantastic numbers. This issue is one of phenomenon about archetypal image that found in real life.

Leaving children from sunset to darkness is believed that the spirit scatters them (Kurniawan, 2019). This myth is trusted by the society in Melayu Sambas. The theory of Carl Jung discusses the darkness related to the crime, murder, and death. The night as the image is associated with the darkness and the evil as the symbols. Those are the symbols appearing in the society.

This study discusses the phenomenon of archetypal images found in the novel "Maleficent" by Elizabeth Rudnick in 2014. The advantage of this study is people will understand the interpretation of symbols to see or feel the image because it is a common symbol in their lives. Then, people can explain the idea of the symbol without the need to be taught. Compared to previous studies, the reader is able to describe and better understand each symbol in archetypal images found in everyday life.

\section{LITERATUR REVIEW}

Every person understands the meaning of each image, archetypal image was built from collective unconscious. Human usually calls it as a symbol. It makes easier to understand and sometimes it increase's by the time. (Hardanto et al., 2019) said that each culture in a place has their own symbol which could be understood by their self. Therefore, the understanding of archetypal image is also influenced by the environment.

(Jung, 2018) purposed the terminology of archetypal images in. The book entitles Archetypes and Collective Unconscious. He explained that archetypal 
image can be accessed by all human like database in a server. He also explained that it was a reservoir of the experience as a species, humans' knowledge of all the "psychic inheritance" carried with birth. Human never realizes it directly but only knows it indirectly by looking at its effect on all our behavior, especially those that are emotional. Jung added about archetypal image that often found in literary works in fantasy genre.

Archetypal image is certainly easier found in literary work in fantasy genre. One example of them is the wise old man found in Harry Potter novel J.K. Rowling. It can be concluded that wise old man symbolized by Dumbledore. It knew based on the statement by (Jung, 2018), he described the wise old man is a man who protects, teaches, and helps the main character.

Indeed, (Jung, 2018) explained that archetypal image is universal symbol. It means many archetypal image that we know the meaning by seeing and feeling the image. Because of that (Guerin et al., 2005) categorized archetypal image more specific into fourteen archetypal images based on Jung`s understanding. Those are water, sun, color, circle, serpent, number, the archetype woman, the demon lover, the wise old man, the trickster, garden, tree, desert, and mountain.

Jungian images in (Guerin et al., 2005) explained that each archetypal image has sub image. Those are:

\section{Water}

This archetypal image has two sub images. Those are sea and river. Sea is symbolized as mother of life, spiritual mystery. While, river symbolized is as death and rebirth (baptism), the flowing of time into eternity, phases of life cycle,

Sun

This archetypal image has two sub images also. Those are rising sun and setting sun. Rising sun is symbolized as birth, creation, enlightenment. While, setting sun is opposite of rising sun, it is symbolized as death.

\section{Colors}

This archetypal image has five sub images. Those are red, green, black, blue and white. Those also has meaning in each sub images. Red is symbolized as blood, sacrifice, violent passion and disorder. Green is symbolized as fertility, growth, hope and sensation. Then, black is symbolized as something negative, darkness. While, blue is usually symbolized as highly positive, associated with truth. The last sub image is white, it is symbolized as signifying, or another in positive aspect. 
Circle

This archetypal image has four sub images. Those are mandala, egg, yangyin, and ouroboros. Mandala is geometric figure symbolized as unifying center and physic integration. Egg is shape of oval symbolized as mystery of life and forces of generations. Yang-yin is Chinese symbol representing the union of the opposite forces of yang which is symbolized as masculine principle, light and conscious mind. While, yin is symbolized as the female principle, darkness and unconscious. Ouroboros is the last sub image symbolized as eternal cycle of life.

Serpent

This archetypal image is shaped of snake. It is symbolized as energy, evil, corruption, sensuality and mystery.

\section{Numbers}

This archetypal image has four sub images. Those are three, four, five and seven. Three is symbolized as light, spiritual awareness and unity. Four is symbolized as four season. Five is symbolized as signifying integration. Then, seven is special number. It is symbolized as completion of all numbers.

\section{The Archetypal Woman}

This archetypal image has three sub images. Those are the good mother, the terrible mother, and the soul mate. The good mother is positive aspect of the earth mother. It is symbolized as nourishment, protection, abundance. Then, the terrible mother is negative aspect symbolize as witch, sorceress, or something in terrifying aspect. The last is the soul mate. Jung described this image as the princess.

\section{The Demon Lover}

This archetypal image is the counterpart of the terrible mother. It is symbolized as devil, Dracula, Satan.

\section{The wise Old Man}

This archetypal has own page in Jung's book. It really special place because the figure of wise old man is very impact into a character in the story even in the real life. It is symbolized as savior, wisdom, protector and helpful man.

\section{The Trickster}

This archetypal image appears the opposite of the wise old man. It is symbolized as joker, jester, clown, fool, or prankster. 


\section{Garden}

Garden is symbolized as paradise, fertility, innocence and unspoiled beauty.

Tree

Tree is symbolized as denotes life of the cosmos, growth, generative and regenerative process, and transformation process.

Desert

This archetypal image is symbolized as spiritual aridity, death, hopelessness, and nihilism.

Mountain

This archetypal image is symbolized as aspiration, inspiration, meditation and spiritual elevation.

\section{RESEARCH METHOD}

This researcher is a descriptive qualitative research. The object in this research is archetypal images. Data collection procedures are observation (reading) and note-taking technique. The method of data analysis is content analysis and interpreting technique. This researched succeed content analysis in "Maleficent" novel because there are many phenomena of archetypal image found in this novel. Archetypal image is easy to find in fantasy story, one of them is "Maleficent" novel by Rudnick.

\section{FINDINGS}

Water

Data 1

River: "She flew along a rushing river, the water burbling happily over boulders of various sizes. As she saw the rocks, a glimmer came into Maleficent's eyes and she began to gesture with her hands" (page.29).

The incident after two years ago made her able to live without his parents, and began to live independently. Flew along the rushing river it means that he has grown and risen from sadness.

\section{Data 2}

River: "Sensing that Maleficent was unhappy, Diaval plunged ahead, his words running into one another in his rush to get them out - and then get far, far away. "There will be a christening in one month's time. They say it's to be a grand celebration" (Page 68). 
The clue is christening. In Christians a person who is baptized will be drowned in a river, from the data there is a christening sentence which means a rebirth.

\section{Sun}

Data 3

Rising sun: "The sun would be setting at any moment, and he needed to return home with his father" (page 3).

The sentence sun will be setting any moment, in this case is a natural law and humans just follow it. At sunrise all people can do their activities while at sunset all will have difficulty.

\section{Data 4}

Rising sun: "He will bring it with him in case there is a problem. King Henry's seal was sparkling in the sunlight. I will make this kingdom peaceful and prosperous" (page 60).

Stefan king had the ability to make the kingdom prosperous meaning that it contained a clue creative energy.

\section{Data 5}

Rising sun: "Moments later, when the sun began to shine beneath the horizon, Maleficent ran down the path behind the horse in full force to save Aurora from its curse" (page 60).

The appearance of the sun has an impact on the strength of Maleficent to carry out the action.

\section{Data 6}

Rising sun: "As he watched the sun shine brighter he flew into the sky through the clouds and spread his wings to avenge him against the human race" (page 140).

The power increases at sunrise, it means the sun has an important role in a power.

\section{Colors}

Data 7

Red: "He offered his hand, and she reached out to take it. Suddenly, a searing hot flash hit her finger, and she pulled her hand back. Glancing down, she saw his ring had left a red burn" (page 33). 
The situation when they shook hands, Stefan used an iron ring and burned Maleficent's hand until red. From the quotation above the author found the keyword red burn, it refers to something that is red. Therefore, in archetype image of red in this novel symbolize blood.

\section{Data 8}

Red: "Frightened, King Henry raised his armored hand, trying to protect himself from Maleficent. As he did, the iron gently brushed Maleficent's cheek. She let out a gasp and raised a hand to her face. Where the iron had touched her skin, it burned painfully" (page 45).

The war in the Moors between King Henry and Maleficent. It is burn painfully which explain something red. Another explains is that the burn painfully contained in the story is a red bruise due to the touch of steel with skin. So, in the novel red image archetype is symbolized by blood.

\section{Data 9}

Red: "When the iron touches its bleeding flesh, it feels burning pain and hears a hiss when its skin is burning. Unable to handle extreme pain, Maleficent fell to his knees, the net covered him like his wings used to be" (page 156).

The conditions found clue bleeding which means at that time he suffered and bled.

\section{Data 10}

Green: "In the middle of the forest grows very large and magnificent green plants, the stems of the plant are twisted into long, thick branches, then descend into the mossy maze that has perfect roots. Shiny leaves covered the branches, and when the moon caught it right, they threw a green light that illuminated the grass" (page 16).

They are large and live there because they have kept many sources of life and their food is fulfilled besides being free from enemy attacks.

\section{Data 11}

Green: "Hermia," called a warm voice behind her. Suddenly, a tall, handsome faerie appeared by her side. It was her husband, Lysander, his green eyes gleaming as brightly as the stars above them" (page 17).

A wife was sleeping her child at night, then the husband came by showing a teasing expression on his wife. From the above quote the author found the keyword green eyes gleaming. So that the keywords above express a sensation and a growing passion. Thus, the archetype image of green symbolized growth and sensation. 


\section{Data 12}

Green: "Tall trees soared into the air and thick green vegetation covered the ground. The fairies and other aliens enjoyed the beautiful morning" (page $35)$.

Green means the conditions there are very fertile so there is a lot of life.

\section{Data 13}

Blue: "Leila looked nothing like Maleficent, her locks golden and curled, not ebony and straight, her eyes warm and blue instead of a piercing green" (page 32).

Beauty and kindness of King Stefan's wife makes him always comfortable and beautiful to look at, contrary to Maleficent. Blue eyes which means in the novel is a kindness and sincerity. Thus, the archetype image of blue is symbolized as highly positive.

\section{Data 14}

Black: "The sky grew darker and black, and the sounds of nature became louder. There were the hoots of owls, the cawing of crows, and the buzzing drone of bugs as they went from flower to flower" (page 35).

From the quotation above, the author explains about the situation of the place around the Moorish kingdom which is famous for witchcraft and darkness that surrounds the kingdom. So that not many people dare to go there. The clue of the quotation above is black symbols. In the quote above the researcher found the clue screaming owls and the sound of crows, where the owls and crows are black. Thus, the archetype image of black in this novel is symbolized mystery and evil.

\section{Data 15}

Black: "From the other side of the hill, two enormous black wings appeared through the mist" (page 43).

A pair of black wings which symbolizes the black color is a mystery. in this case the mysterious power can be obtained from these wings to fight the enemy.

\section{Data 16}

Black "Then there was a pair of sharp and crooked black horns, slowly Maleficent rose to the water, looking like a creature from hell with only fog and no troops" (page 43). 
The horn owned by the maleficent signifies a symbol of evil.

\section{Data 17}

Black: "Henry yelled to his troops, "Bring me her head!" (page 43).

The war that took place between Maleficent and King Henry. Maleficent does not recognize Henry as a king so he wants the head of Maleficent, from the above quote the researcher concludes that there will be a death that wants maleficent to die.

\section{Data 18}

Black: "He saw a black crow who had visited the ruins trapped under a thick net. The dogs growled at the crow, causing the creature to flap its wings in panic. But there is no place for him to go" (page56).

In the archetype image of a black crow is a mystery and death, in this case the crow is assigned to carry out a task of crime that is monitoring the situation by humans.

\section{Data 19}

Black: "She threw her little arms around Maleficent's legs and buried her head in the faerie's long black robes" (page 87).

He used a long black robe signifying the symbol of evil to carry out the action.

\section{Data 20}

White: "His skin was almost colorful, like a trickle of white dew, and his colorful wings were enticing when they fluttered behind him. He was the most beautiful thing that boy had ever seen" (Page 13).

The atmosphere in that place still natural and has not been disturbed by humans who make fairies roam there. The author found the keyword brilliant blue faerie climbed onto the rock, it shows that the situation there is still safe and fertile.

\section{Serpent}

\section{Data 21}

Serpent: "Letting out a piercing scream, she raised her staff, shooting a lightning bolt into the dark sky" (page 66).

In this image there is a black snake shaped stick that has magic power. In the image archetype is interpreted as a symbol of evil energy. 


\section{Numbers}

\section{Data 22}

Three: "The three fairies came to the baptism "Knotgrass was the first to say something. "Sweet Aurora," she began. "I wish for you the gift of beauty." Reaching down, she touched the sleeping baby's blond curls. Next, Flittle granted a wish. "My wish," she said, "is that you'll never be blue, only happy all the days of your life" (page 43).

The events in the kingdom during baptism. The three fairies are good fairies, they say good wishes to babies and they do not like war proven when King Stefan leaves Aurora to keep watch. The author finds the clue from the words Flittle and Knotgas: happiness and beauty, so it is concluded that the hope given by the three fairies is included in the archetype of the image.

\section{The Archetypal Woman}

\section{Data 23}

The good mother:

"She hummed a lullaby and raised one hand above her, making night blossoms suddenly unfurl on the branches overhead. Then she made the leaves and flowers dance, swaying to the tune of her song, as her daughter was lulled to sleep" (page 4).

Hermia, Maleficent's mother is a good mother who gives comfort, keeps her child to sleep and gives beautiful songs.

\section{Data 24}

The good mother:

"Keep sleeping, love," he whispered to her. "We'll look after you" (page 21).

In the statement above concluded that Finch had the soul of a mother even though the baby was not his child but he cared for him well.

\section{Data 25}

The good mother:

"Maleficent would cry and tell her everything, and then her mother Hermia would kiss her forehead and tell her it would be all right" (page 41).

In the statement above concluded that his mother was a good person, he tried to make his child calm and not disappoint him even though his mother would leave him to fight the human race. 


\section{Data 26}

The terrible mother:

"Whenever he said silly things, his mother would cuff him upside the head and send him out to the barn to clean the stalls" (page 10).

In the above case concluded that the mother did not educate her child well, the mother used more violence in educating her child, the child would feel depressed and not free.

\section{Data 27}

The terrible mother:

"There was one final part to her gift. "But before the sun sets on her sixteenth birthday, she will..." She paused and looked around the room for inspiration. Her eyes landed on one of the presents brought for the baby. She continued... prick her finger on the spindle of a spinning wheel and fall into a sleep like death. Asleep from which she will never awaken" (page 74).

The gift that maleficent give to the baby aurora, that is the curse of magic that made him die at the age of sixteen. The author found the key words from the quote above, the keywords is never awaken. Will never awaken is a word spoken by someone to harm others and this action makes people lose their lives. Based on keywords Maleficent has the character of a terrible mother.

\section{Data 28}

The soul mate:

"And in return for my life, I am your servant" (page 57).

From the above quote found the clue servant, which means that he devoted his life to others and lived with him, became friends and obeyed all his master's orders.

\section{The Wise Old Man}

\section{Data 29}

The wise old man:

"Then he had hooted and hollered, mimicking his father as best he could, to make the furry creatures move on" (page 9).

In the archetype image, the wise old man is a man who can teach someone well, in the quote above a child works as a shepherd and imitates his father's good qualities. 


\section{Garden}

Data 30

Garden: "There were natural resources, such as fresh water and plentiful forests. And it was rumored that the streams were filled with jewels. Taking over the Moors would make his kingdom much more powerful" (page 42).

The garden is very fertile and there is abundant wealth that can provide for the lives of those who live there.

\section{Data 31}

Garden: "A very large and magnificent tree, the trunk of the tree twisted into long, thick branches, then descended into a mossy maze that was perfectly rooted. Shiny leaves covered the branches, and when the moon caught it right, they threw green light that illuminated the grass" (Page 16).

There are large and magnificent trees that have thick leaves that cover the branches, have perfect roots, from the quotation above explains that the location where the tree is a fertile field and paradise for plants there.

\section{Tree}

\section{Data 32}

Tree: "Most of the Moorland creatures were asleep, some tucked in the leaves on the ground, others resting in trees. Through it all, a sleeping Aurora floated" (page 105).

The situation at the Moor at night, they mostly choose to stay in a tree because there they feel comfortable and thrive there their needs are also met. This section includes discussion from the findings of conducted research. In this section, it is necessary to compare the findings of research with relevant research findings.

\section{DISCUSSION}

From the data analysis above, researchers found several results. There are nine out of fourteen images found from the novel Maleficent by Elizabeth Rudnick's novel. The image that emerges based on the theory put forward by (Jung, 2018);(Boyer, 2014). Everyone has different traits, personalities, and archetypal. At a certain moment someone used to bring up a different type of image also because it depends on the person facing the problem, whether avoiding or even facing it (Jung, 2018). Many images that appeared in our daily live. The image "black" is symbolized by chaos, mystery, and death. So that in a tragedy or fairy tale if we find a crow that chirp, especially at night, it is believed that there will be disaster and even death. Symbols appear in various forms, sometimes appearing in different visual forms and themes but are combined with other symbols, thus forming an illustration, artifacts, creative products such as films, 
comics, games or works of art (Jung, 2018). People recognize symbols by seeing or feeling their image because it is a common symbol in their lives. Then, people can explain the idea of the symbol without the need to be taught. If someone sees "water" then they will realize that it is a very important source of life for sustaining life, besides that water is useful for agriculture, rice fields and for other animals.

Novels as a type of literary work arranged in narrative form. Forms of style, structure and narrative techniques in the novel are depicted by its value system and can be enjoyed in the literature. Novels certainly have genres such as in stories, such as romance, horror, mystery, humor, biography, history, and fantasy. The novel genre given is based on the content or phenomena in the story. (Jung, 2018) explain that archetypes formed by collective unconscious related to aspects of life. In this case, the archetypal image can be found in the novel "Maleficent" by Elisabeth Rudnick so that it is appropriate to analyze the basic drawing pattern by Jung. This novel tells the story of another personality character from an evil fairy who turns out to also have a gentle, kind and compassionate heart, this trait changes the view of each audience.

\section{CONCLUSION}

The archetypal image has their respective symbol in interpreting the images. It was found 32 data. The images are water (river), sun, colors (red, green, blue, black, white), serpent, number (three), good mothers, wise old man, garden, and tree. Then, the researchers did not find the circle image, the demon lover, the trickster, desert, and mountain because in the novel no existed. The existence of the images in the novel supports the elements of pleasant situation that is imagined but it is unlikely to happen.

\section{REFERENCES}

Boyer, R., L. (2014). 8. A Study of Fitcher's Bird and Little Red Cap. The Rebirth Archetype in Fairy Tales. 2(3), 1-6

Danesi, M. (2004). Messages, Signs, and Meanings. In U. of T. Marcel Danesi (Ed.), A Basic Textbook Semiotics and Communication Theory (Third Edit, p. 368). Canadian Scholar'sPress Inc.

Guerin, W., L., Labor, E., Morgan, L., Reesman, J. C., \& Willingham, J. R. (2005). A Handbook of Critical Approaches to Literature (Fifth Edit). Oxford Univeristy Press.

Hardanto, E., Natsir, M., \& Kuncara, S. D. (2019). An Analysis of Smeagol's Character Influenced by the One Ring in Lord of the Rings: Return of the King Film Using Jung archetypes. Jurnal Ilmu Budaya, 3(1), 106-120.

Kay, B. \&. (1969). Color Science and Technology. Encyclopedia of Color Science and Technology, 8-11. https://doi.org/10.1007/978-3-642-27851-8

Kurniawan, S. (2019). Pantang Larang Bermain Waktu Magrib (Kajian Living Hadis Tradisi Masyarakat Melayu Sambas). Jurnal Living Hadis, 4(1), 1. https://doi.org/10.14421/livinghadis.2019.1629 
2020. Linguistics, English Education and Art (LEEA) Journal 3 (2):506-519

Jung, C. (2018). Expert Witness and Jungian Archetypes. United States: Harvard Medical School.

M.R., Y. (2017). Makna Ground dalam Cerpen Uak dan Burung Gagak. Jurnal Ilmiah Kebahasaan dan Kesastraan. 3(2), 10-20 